Cilt / Volume: 2

Sayı/ Issue: 2

Kiş / Winter 2021

D S e l çu k Üniversitesi

İslami İlimler Fakültesi Dergisi

\title{
Hastalık ve Dua İlişkisine Yönelik Yapılan Çalışmalar Üzerine Literatür Değerlendirmesi (1990-2020)
}

\section{Ayşe Selin DOKUR}

Doktora Öğrencisi, Sakarya Üniversitesi, Sosyal Bilimler Enstitüsü, Din Psikolojisi Ana Bilim Dalı

Ph. D. Candidate, Sakarya University, Institute of Social Sciences, Department of Psychology of Religion

Sakarya, Türkiye

@dokurselin@gmail.com

https://orcid.org/ 0000-0002-9294-8506

Mehmet Emrullah DURAN

Arş. Gör., Selçuk Üniversitesi, İslami İlimler Fakültesi, Din Bilimleri Ana Bilim

Dalı

Res. Asst., Selçuk University, Faculty of Islamic Studies, Department of Religious Studies

Konya, Türkiye

emrullahduran@selcuk.edu.tr (D) https://orcid.org/0000-0001-9952-5103 


\section{Hastalık ve Dua İlișkisine Yönelik Yapılan Calıșmalar Üzerine Literatür Değerlendirmesi (1990-2020)}

Son yıllarda artan din psikolojisi çalışmalarında din, dindarlık ve maneviyatın bedensel ve ruhsal hastalıkların üzerindeki etkisini inceleyen pek çok saha araştırmasının yapıldığı görülmektedir. Bu çalıșmada hastalık ve dua konusunda 1990-2020 yılları arasında yapılmıș çalışmaların taraması gerçekleștirilmiștir. Bu bağlamda çalışmamızda hastalık ve dua konusunda çalışma yapmak isteyen araştırmacılar için bir veri sağlanması ve ortaya çıkacak verilerin yapılacak araștırmalarda kaynak olması amaçlanmaktadır. Araștırmamızda nitel araștırma tekniklerinden durum çalıșması deseni kullanılmıștır. Araștırmamız neticesinde șu sonuçlara ulaşılmıştır: Yapılan çalıșmada yayımlanan çalıșmaların yıllara göre dağılımı dikkate alındığında en çok 2007 (n=8) yılında, en az ise 2006 ( $n=1), 2014(n=1), 2015$ (n=1), $2016(n=1)$ ve 2018 (n=1) yıllarında yayımlandığı görülmüștür. Aynı zamanda çalımaların incelenmesi sonucunda anket, deney, görüşme/mülakat, belge tarama/dökümantasyon ve gözlem şeklinde 5 başlık belirlenmiş ve çalışmalar buna göre sınıflandırılmıștır. İncelenen araştırmalar arasında en fazla anket tekniğinin $(n=41)$ kullanıldığı saptanmıștır. İncelenen 87 lisansüstü tez ve makale çalışmasında örneklem olarak toplam 7 çalışma grubu tespit edilmiștir.

Özet Anahtar Kelimeler: Din Psikolojisi, Psikoloji, Din, Hastalık, Dua.

\section{A Literature Review On The Studies On The Relationship of Disease and Prayer (1990-2020)}

In recent years, it is seen that many field studies examining the effects of religion, religiosity and spirituality on physical and mental diseases have been carried out in the studies of illness and prayer relitionsip that have increased in recent years. In this study, general studies on illness and prayer were conducted between 1990 and 2020. In this context, our study aims to provide data for researchers who want to work on illness and prayer, to present the researched positive psychology concepts by arranging them, and to be a source for future research. In this context, our study aims to provide data for researchers who want to work on illness and prayer, and to be a source for future research. Our study follows the case study pattern, a qualitative research technique. As a result of our research, the following conclusions were reached: An analysis of the distribution of the published theses by year reveals that the highest number of theses were published in $2007(\mathrm{n}=8)$, the least in $2006(n=1), 2014(n=1), 2015(n=1), 2016(n=1)$ and $2018(n=1)$. At the same time, as a result of the examination of the studies, 5 titles were determined as questionnaire, experiment, interview/interview, document scanning/documentation and observation and the studies were classified accordingly. It was determined that the survey technique $(n=41)$ was used the most among the studies examined. A total of 7 study groups were identified as samples in the 87 postgraduate theses and articles examined.

Abstract $\quad$ Keywords: Psychology of Religion, Psychology, Religion, Illness, Prayer.

\section{Giriş}

Son çeyrek asırda ülkemizde önemli bir gelişme gösteren din psikolojisi çalışmaları her geçen gün artmaktadır. Din, dindarlık ve maneviyatı psikolojik perspektifle inceleyen din psikolojisinin bașlıca çalıșmalarından birisi de dinimanevi alanın ruhsal ve bedensel hastalıklar üzerindeki etkisinin araştırılmasıdır. Dindarlık ve maneviyatın insan sağlı̆̆ı üzerinde olumlu etkilerinin olduğunu gösteren çalışmalarla birlikte dindarlık göstergelerinden 
biri olan duanın ruhsal ve bedensel rahatsızlıklar üzerindeki etkilerini inceleyen pek çok araştırmalar da literatürde yer almaktadır.

Dua, Arapça 'da "da'vet ve da'va” köklerinden gelmekte olup, “çağırmak, seslenmek, sevk etmek, herhangi bir şekilde söz ya da ses ile bir şeye yönelmek" anlamları ihtiva etmektedir. ${ }^{1}$ İngilizce 'de dua sözcüğü (prayer, devotions, blessing), "Bireylerin Tanrı'ya teşekkürlerini sunması ya da Tanrı'dan yardım dilemesi" şeklinde tanımlanmaktadır. ${ }^{2}$ Türkçe Sözlükte dua, "Tanrı'ya yalvarma" ve "ibadet ya da yakarma amacıyla okunan dini değeri olan metin" olarak ifade edilmiștir. ${ }^{3}$ Psikoloji sözlüğünde ise dua, "insanın tabiatüstü varlık ya da varlıklarla iletişime girdiği etkinlik" olarak tanımlanmıștır. ${ }^{4}$

Geçmişten günümüze tüm din ve inanışlarda bireyler, ilahi olana yönelmek amacıyla çeşitli şekillerde dua ibadetine başvurmuşlardır. Yahudilikte dua için kullanılan kelime "tefila" dır. Yahudi inancında tanrıya yaklaşmanın başlıca araçlarından biri olarak kabul edilen dua, insanlar ile tanrı arasındaki kişisel ilişkinin özü olarak kabul edilmektedir. ${ }^{5}$ Hristiyanlıkta dua diğer dinlerde olduğu gibi büyük önem taşımaktadır. Hatta bazı kaynaklarda dua dini törenlerden daha önemli görülmektedir. Hristiyanlıkta her duruma özel ayrı bir dua mevcuttur. Örneğin; hastalık, ölüm, yağmur, yolculuk, evlenme, kutsama vb. durumlarda sıklıkla duaya başvurulmaktadır. ${ }^{6}$ İslâm dini de bireyin var oluş gayesini bir diğer ifadeyle bireye verilen değeri duaya bağlamıştır. Furkan Suresi'ndeki "Duanız olmasa Allah size ne diye değer versin?" ayeti duanın Yaratıcının nezdindeki önemini göstermektedir. ${ }^{7}$ Bununla birlikte Kur'ân-ı Kerim'de "dua" sözcügü yirmi yerde geçmekte olup ayrıca pek çok ayette dua kökünden fiillerde yer almaktadır. ${ }^{8}$ Kur'ân-ı Kerim'de hastalık ve dua ilişkisine dâir birçok ayet bulunmaktadır. Bunlardan birisi de Enbiya Suresi seksen üçüncü ayettir. "Eyyûb'u da an! Hani rabbine, "Başıma bu dert geldi. Ama sen merhametlilerin en üstünüsün" diye niyaz etmişti. Bunun üzerine biz, tarafımızdan bir rahmet ve kulluk edenler için anılacak bir örnek olmak üzere onun duasını kabul ettik; kendisinde dert ve sıkıntı olarak ne varsa giderdik; ona aile efradını, ayrıca bunlarla birlikte bir mislini daha verdik." 9

Dünya Sağlık Örgütü (DSÖ) 1948 yılı tüzüğüne göre sağlık "Yalnızca hastalık veya sakatlığın olmaması durumu değil, fiziksel, sosyal ve ruhsal refah durumu" şeklinde tanımlanmıştır. ${ }^{10} \mathrm{Bu}$ tanımdan hareketle çalıșmamızda hastalık

Fâris, 1422/2001.

Collins Cobuild, Adcanced Leraner's English Dictionary (London: Harper Collins Publisher, 1998), "Prayer", 325.

Felsefe Terimleri Sözlüğü (TDK), “Dua”, (Erișim 30 Ağustos 2021).

Halil Apaydın, Din Psikolojisi Terimler Sözlüğü (İstanbul: Bilimkent Yayınları, 2016), 86.

Âdem Özen, Yahudilikte İbadet (İstanbul: Ayıșığı Kitapları, 2001), 71.

Ali Erbaş, Hristiyanlıkta İbadet (İstanbul: Ayıșığı Kitapları, 2003), 48.

Kur'ân Yolu (Erişim 30 Ağustos 2021), el-Furkân 25/77.

https://islamansiklopedisi.org.tr/dua (TDV, 7 Eylül 2021).

Kur'ân Yolu (Erișim 30 Ağustos 2021), Enbiyâ 21/83-84. Dua ile ilişkili Kur'ân-ı Kerim'de geçen başka ayetler için bkz. Bakara 2/186; En'âm 6/41; En'âm 6/63-64; A'raf 7/56; A'raf 7/180; Tevbe 9/103; Yunus 10/12; Neml 27/62; Rum 30/33; Mü’min 40/60; Şûrâ 42/26.

10 World Healt Organization, Healt Promotion Glossary (Geneva: World Healt Organization,1998), 1. 
kavramı altında hem bedensel hem de ruhsal rahatsızlıklar temel alınmıştır. Literatür incelendiğinde dua ile ilgili yapılmış araştırmaları dört ana başlık altında toplayabiliriz:

1) Dua ve Kanser Hastalıkları Araştırmaları: Geçmişten günümüze kanserle başa çıkmada hastaların duaya başvurmaları pek çok çalışmaya konu olmuştur. Örneğin; Sodestrom ve Martinson (1987) tarafından yapılan araștırmada hastaların kanserle baș etmede en sık kullandıkları manevi stratejinin dua yöntemi olduğu tespit edilmiştir. ${ }^{11}$ Aynı șekilde Johnson ve Spilka (1991), Raleigh (1992), Mickley ve ark. (1992), Halstead ve Fernsler (1994), Roberts ve ark. (1997), Mao ve ark. (2007), Levine ve ark. (2009), Yates ve ark. (2005), Ambs ve ark. (2007), Rezaei ve ark. (2008), Smith ve ark. (2012), Jors ve ark. (2015) tarafından yapılmıș araștırmalarda da kanser hastalarının hastalıkla mücadelede sıklıkla duaya başvurdukları sonucuna ulaşılmıştır.

2) Dua ve Kalp-Damar Hastalıkları Araştırmaları: Miller (1982), Leserman ve ark. (1989), Ai ve ark. (1998), Harris ve ark. (1999), Aviles ve ark. (2001), Leibovici (2001), Benson ve ark. (2006), Dein ve ark. (2012) ilgili araştırmalarda kalp-damar hastalarının hastalık sürecinde duaya yöneldiği ve duanın tedavi sürecine olumlu katkısı olduğu tespit edilmiştir.

3) Dua ve Anksiyete Hastalıkları Araştırması: Morris (1982), Carlson ve Ark. (1988), Kabat-Zinn ve ark. (1992), Azhar ve ark. (1994), Palmer ve ark. (2004), McCaffrey ve ark. (2004) tarafından yapılmış araştırmalarda da duanın anksiyete bozukluğu olan hastalar üzerinde istatistiksel olarak anlamlı ve klinik açıdan önemli derecede anksiyete azalması olduğu tespit edilmiştir.

4) Dua ve Depresyon Hastalıkları Araştırmaları: Azhar ve Varma (1995), O’laoire (1997), Kendler ve ark. (1997), Koenig ve ark. (1998), Braam ve ark. (2007), Maltby ve ark. (2008) tarafından yapılmış çalışmalarda dua eden hastaların depresyon belirtilerinde azalma olduğu, daha yüksek yaşam kalitesine ulaştıkları saptanmıştır.

Bu çalışmada hastalık ve dua konusunda 1990-2020 arasındaki yıllarda yapılmış lisansüstü tezlerin taraması yapılmıștır. Çalışmamızda var olan verileri, bütüncül ve eleștirel tarzda değerlendirerek literatürdeki yönelimler, olumlu ve olumsuz/eksik yönler hakkında sonuçlar üretmek amaçlanmaktadır. Çalışmamızda tezlere ilişkin sayısal veriler, tezlerin yıllara, üniversitelere, içerdikleri konulara ve veri toplama tekniklerine göre dağılımına yer verilmiştir. Bununla beraber incelemeye tabi tutulan 87 çalışma, alfabetik sırasına göre yazar soyadı, tez adı, üniversite ve yıl bilgisi liste şeklinde çalışmaya eklenmiştir.

\section{Yöntem}

\subsection{Araştırmanın Modeli}

$\mathrm{Bu}$ araștırma betimsel tarama modelinden biri olan nitel araștırma tekniklerinden faydalanılarak hazırlanmıştır. Veri toplama yöntemi olarak doküman incelemesinden yararlanılan araştırmanın veri analiz kısmında ise

11 K. E. Sodestrom, M. Martinson. "Patients Spiritual Coping Strategies: A Study of Nurse and Patient Perspectives”, Oncol Nurs Forum 14/2 (1987). 
durum çalışması deseni kullanılmıştır. "Durum çalışmaları gerçekte ortamda neler olduğuna bakma, sistematik bir biçimde verileri toplama, analiz etme ve sonuçları ortaya koyma yoludur. Ortaya çıkan ürün ise, olayın niçin o şekilde olduğunun ve gelecek araştırmalar için daha detaylı olarak nelere odaklanmanın gerektiğinin keskin bir biçimde anlaşılmasıdır."12 Bununla birlikte durum değerlendirmesi diğer yöntemlerle elde edilmiş gözden kaçabilecek ayrıntılı bilgilerin detaylı incelemesini de imkânlı kılar. ${ }^{13}$

Bu çalışma özelinde 1990-2020 yılları arasında hastalık ve dua konusu ile ilgili yapılan lisansüstü tezlerin ve makalelerin süreç içerisinde yıllara göre yöneliminin durum çalışması kullanılarak incelenmesi amaçlanmıştır.

\subsection{Evren ve Örneklem}

Araştırma kapsamına alacağımız hastalık ve dua konusunda yayımlanmış lisansüstü tezlere Yükseköğretim Kurulu (YÖK) Ulusal Tez Merkezi verileri, Google Akademik veri tabanı ile İSAM İlahiyat Fakülteleri Tezler Kataloğu ve İlahiyat Makaleler veri tabanı arasındaki veriler karşılaştırmalı şekilde incelenerek ulaşılmıştır. Ulaşılan 97 çalışmadan, 10'u çalışmamızı sınırlandırmış olduğumuz tarihlerin kapsamı dışında kaldığından dolayı araștırmaya dâhil edilmemiștir. Geriye kalan 87 araștırma çalışmanın örneklemi olarak belirlenmiştir.

\subsection{Verilerin Toplanması ve Analizi}

$\mathrm{Bu}$ çalışmanın verileri YÖK Ulusal Tez Merkezi, Google Akademik veri tabanı ve İSAM İlahiyat Fakülteleri Tezler Kataloğu ve İlahiyat Makale veri tabanından yararlanılarak toplanmıştır. Toplanan 87 lisansüstü tez bilgisayar üzerinden Excel ortamına aktarılarak önce tez adı, üniversite, yıl, konularına ve veri toplama tekniklerine göre listelenerek tablolaștırılmıștır.

\section{Bulgular}

Çalışmanın bu bölümünde araştırmaya dâhil edilen çalışmalara ilişkin bulgulara yer verilmiştir.

\subsection{Elde Edilen Lisansüstü Tezlere İlişkin Sayısal Veriler}

Bu kısımda araştırmaya dâhil edilen 14 tez ve 73'ü makale olarak yayınlanmış olan toplam 87 çalışma incelenmiştir. Elde edilen bulgular tablo şeklinde aşağıda verilmiştir.

12 Berrak Aytaçlı, "Durum Çalışmasına Ayrıntılı Bir Bakış”, Adnan Menderes Üniversitesi Eğitim Fakültesi Eğitim Bilimleri Dergisi 3/1 (2012).

13 Gül Kaleli Yılmaz, "Durum Çalıșması", Kuramdan Uygulamaya Eğitimde Bilimsel Araştırma Yöntemleri, ed. Mustafa Metin (Ankara: Pegem Akademi, 2014), 264. 


\begin{tabular}{|c|c|c|c|c|}
\hline ue $_{[} \mathrm{do}_{L}$ & $\dddot{r}$ & $\Xi$ & $\infty$ & 음 \\
\hline ozoz & $N$ & 1 & $N$ & $N$ \\
\hline $8 \mathrm{LIOZ}$ & - & 1 & -1 & -1 \\
\hline 9L0Z & - & 1 & -1 & -1 \\
\hline SIOZ & - & 1 & -1 & -1 \\
\hline tI0Z & - & ' & -1 & -1 \\
\hline ZLOZ & t & ' & $\theta$ & n \\
\hline ILOZ & $m$ & 1 & $m$ & H \\
\hline OLOZ & $N$ & - & $m$ & 4 \\
\hline $600 z$ & 0 & 1 & 0 & N \\
\hline $800 z$ & 6 & 1 & 0 & n \\
\hline$\angle 00 Z$ & $r$ & - & $\infty$ & a \\
\hline $900 z$ & - & ' & -1 & -1 \\
\hline sooz & $N$ & - & $m$ & $m$ \\
\hline tooz & $n$ & $N$ & $N$ & $\infty$ \\
\hline$\varepsilon 00 z$ & - & $N$ & $m$ & $\theta$ \\
\hline $\mathrm{zo0z}$ & $\checkmark$ & $N$ & 0 & n \\
\hline Lo0z & $N$ & $m$ & 10 & 0 \\
\hline $000 z$ & $m$ & - & $\theta$ & in \\
\hline $666 \mathrm{I}$ & $N$ & 1 & $N$ & $N$ \\
\hline $866 \mathrm{I}$ & $m$ & 1 & $m$ & H \\
\hline$\angle 66 \mathrm{I}$ & $m$ & 1 & $m$ & $\theta$ \\
\hline S66I & $N$ & 1 & $N$ & $N$ \\
\hline t66I & $m$ & 1 & $m$ & $\theta$ \\
\hline$\varepsilon 66 \mathrm{I}$ & - & - & $N$ & $N$ \\
\hline Z66I & $N$ & 1 & $N$ & $N$ \\
\hline I66 I & $N$ & 1 & $N$ & $N$ \\
\hline $066 \mathrm{I}$ & $N$ & 1 & $N$ & $N$ \\
\hline 现 & $\frac{\frac{0}{\pi}}{\frac{\pi}{3}}$ & $\stackrel{N}{\mathbb{N}}$ & ฏ & $\partial^{\circ}$ \\
\hline
\end{tabular}

光:

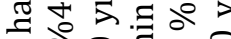

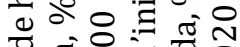
ఏ。̃ 可

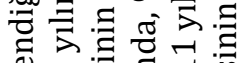
ब $\vec{m} \Xi \vec{\jmath}$ ป ๙ $\Xi$ 긍 그웡ㅇㅀㅇ 음

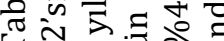
ग 2 व

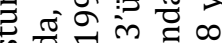

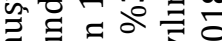

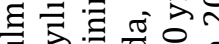
ㄴ. ऊ 을 ๘

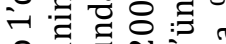
을 츠요 ๘̊ छี

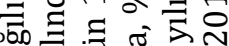

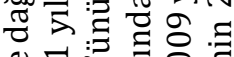
0

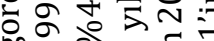
bor $m \cong$ वे ๘

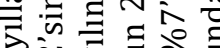
入ㅊ:亏

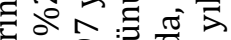
त త్ర

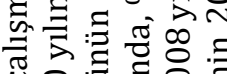

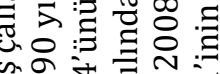
n. घ

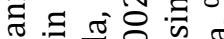
E $\Xi$ 代 ป

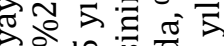

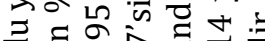

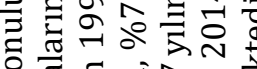

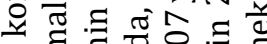

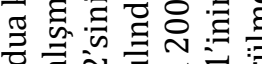

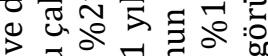
ฟ

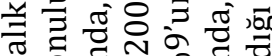

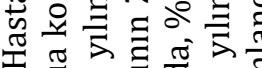
ङ ऊँ

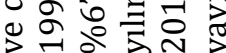




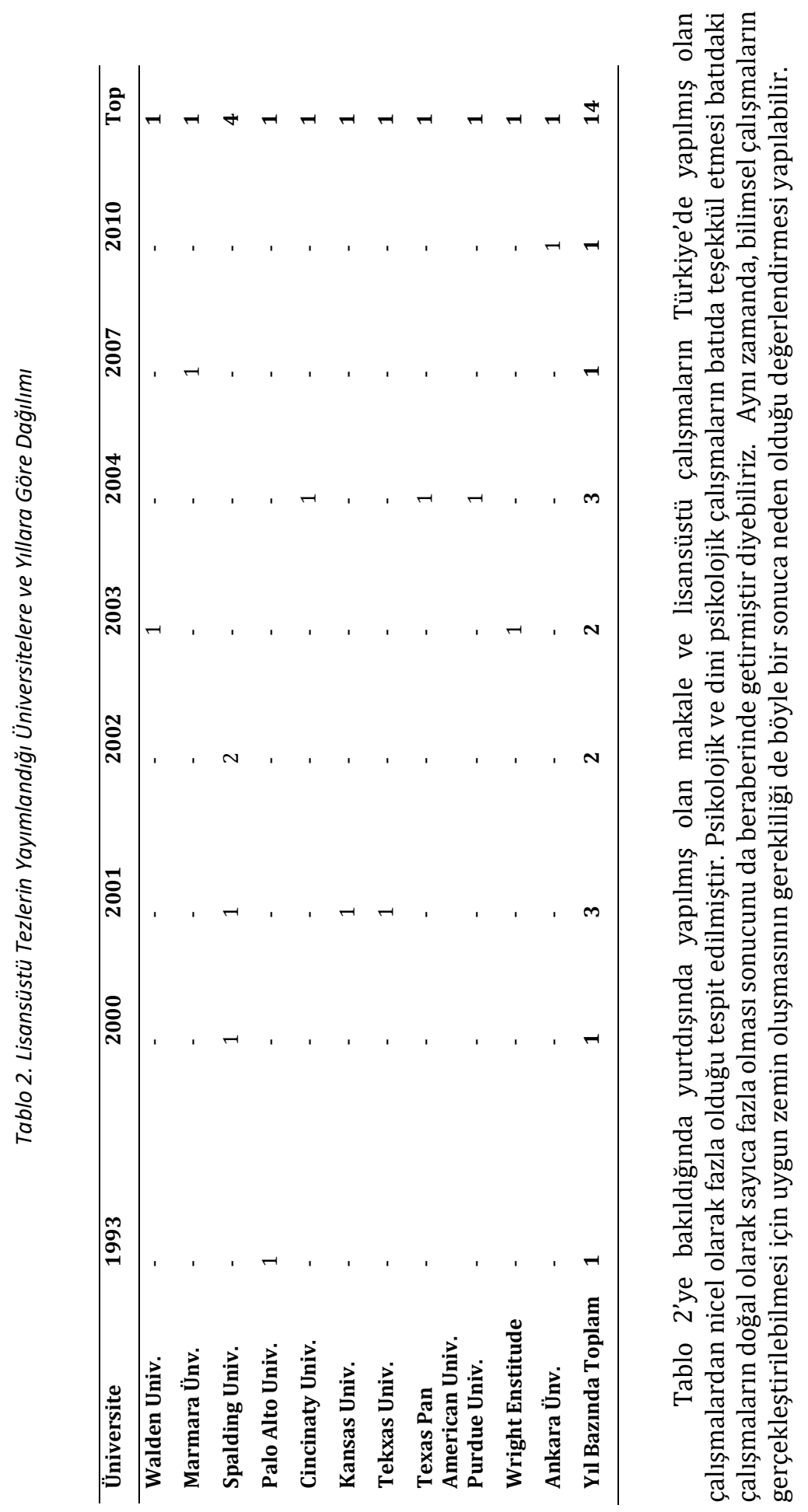




\begin{tabular}{|c|c|c|c|c|c|c|c|c|}
\hline do & $\stackrel{20}{\sim}$ & n & $\stackrel{\infty}{+}$ & $\infty$ & -1 & -1 & - & $\bar{\infty}$ \\
\hline ozoz & ' & ' & - & $\neg$ & ' & ' & ' & N \\
\hline $8 L 0 z$ & ' & $\neg$ & ' & ' & ' & ' & ' & - \\
\hline SLOZ & ' & ' & $\neg$ & ' & ' & ' & ' & - \\
\hline †Loz & ' & ' & ' & $\neg$ & ' & ' & ' & -1 \\
\hline zLoz & $\neg$ & ' & N & ' & ' & ' & ' & $m$ \\
\hline ILoz & ' & ' & N & ' & ' & ' & ' & N \\
\hline $0 L 0 Z$ & ' & $\sim$ & - & ' & ' & ' & ' & $m$ \\
\hline $600 z$ & ' & ' & $\theta$ & ' & ' & ' & ' & $\sigma$ \\
\hline $800 z$ & $\dashv$ & ' & $\theta$ & ' & ' & ' & - & 0 \\
\hline$\angle 00 z$ & - & $\dashv$ & $\theta$ & ' & ' & $\neg$ & ' & n \\
\hline $900 z$ & ' & ' & N & ' & ' & ' & ' & $N$ \\
\hline sooz & $\neg$ & . & N & ' & ' & . & ' & $m$ \\
\hline t00z & $\neg$ & - & $m$ & $\neg$ & - & ' & ' & n \\
\hline$\varepsilon 00 z$ & $\dashv$ & . & ' & $\dashv$ & . & ' & . & $N$ \\
\hline$z 00 z$ & $\neg$ & $\neg$ & $\sim$ & $\dashv$ & ' & . & ' & in \\
\hline I00z & ' & ' & $m$ & $\sim$ & ' & ' & ' & in \\
\hline $000 z$ & $\neg$ & . & N & - & ' & ' & . & $\sigma$ \\
\hline $666 \mathrm{I}$ & - & ' & - & ' & ' & ' & ' & N \\
\hline 866I & ' & ' & $m$ & ' & ' & ' & ' & $m$ \\
\hline$\angle 66 \mathrm{I}$ & $\sim$ & ' & N & ' & ' & ' & ' & $\theta$ \\
\hline S66I & ' & ' & N & ' & ' & ' & ' & $m$ \\
\hline t66I & ' & ' & $m$ & ' & ' & ' & ' & $m$ \\
\hline$\varepsilon 66 \mathrm{I}$ & $\sim$ & ' & . & ' & ' & ' & ' & $m$ \\
\hline z66I & ' & ' & $m$ & ' & ' & ' & . & $m$ \\
\hline I66I & ' & - & $\dashv$ & ' & ' & ' & ' & N \\
\hline $066 \mathrm{I}$ & $\sim$ & ' & ' & ' & ' & ' & ' & -1 \\
\hline 芯 & 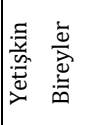 & 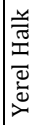 & 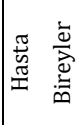 & 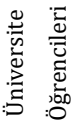 & $\begin{array}{l}\frac{\pi}{0} \\
\frac{\pi}{0} \\
\frac{t}{0}\end{array}$ & 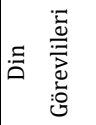 & 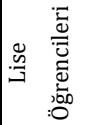 & 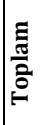 \\
\hline
\end{tabular}


Araştırmalarda tercih edilen çalışma gruplarının analizinden elde edilen bulgulardan 1 ve üzerinde araştırmaya konu olmuş 7 farklı çalışma grubu tespit edilmiştir. Bu gruplar içerisinde en fazla çalışılan grup, hasta bireyler $(n=48)$ en az çalışılan gruplar ise yerel halk ( $\mathrm{n}=7)$, doktorlar $(\mathrm{n}=1)$, din görevlileri $(\mathrm{n}=1)$ lise öğrencileri $(n=1)$, sporcular $(n=1)$ ve esnaflar $(n=1)$ olduğu görülmektedir. İlgili tablo incelendiği zaman konuların ve örneklemin güncel olarak çeşitlendiği görülmektedir. Örneğin ilgili çalışmaların ilk dönemlerde yetişkin bireyler ve yerel halk üzerine yoğunlaşırken zaman içerisinde üniversite öğrencileri, doktorlar, din görevlileri ve lise öğrencileri gibi örneklem gruplarını da kapsadığı gözlemlenmiştir. Lisansüstü çalışmalarda alana katkı sağlanması hedefiyle konuların ve örneklemin çeşitlendiği görülmektedir. Makalelerde ise yoğun saha araştırmaları neticesinde farklı konu ve örneklem seçiminin konunun detaylıca ve karşılaştırmalı olarak ele alınmasına katkıda bulunması bu çeşitliliğin oluşmasına zemin hazırlamıştır şeklinde yorumlanabilir.

Tablo 4. Veri Toplama Tekniklerine Göre Dağılım

\begin{tabular}{|lr|}
\hline Veri Toplama Teknikleri & Frekans \\
\hline Anket & 41 \\
\hline Deney & 20 \\
\hline Belge Tarama/Dokümantasyon & 9 \\
\hline Görüşme/Mülakat & 18 \\
\hline Gözlem & 2 \\
\hline
\end{tabular}

\subsection{Tez Kataloğu}

1. Collinns F.C. The Use of Prayer and the Self-Reported Anxiety and Depression of Retired Adults. Yayınlanmamış Doktora Tezi, Walden Üniversitesi, 2003.

2. Cooper A. E., An Investigation of the Relationships Among Spirituality, Prayer and Meditation, And Aspects of Stress and Coping", Yayınlanmamış Doktora Tezi, The Wright Institude Graduate School of Psychology, 2003.

3. Çiftçi Aişe, Hastalıklarla Başa Çıkmada Dinin Rolü, Kanser Örneği. Yayınlanmamış Yüksek Lisans Tezi, Marmara Üniversitesi, İstanbul 2007.

4. Day J.A.W., A Developmental Study of the Effects of Intercessory Prayer on Family Relationships. Yayınlanmamış Doktora Tezi, Spalding Üniversitesi, Kentucky 2002.

5. Jacobson J.L. An Exploratory Study Regarding the Effects of Praying for Others on Physical and Mental Health in Older Adults. Yayınlanmamış Doktora tezi, Spalding University, 2002.

6. Kuiper J.T., The Experience of Practicing Centering Prayer: A Heuristic Inquiry. Cincinaty Üniversitesi, Yayınlanmamış Doktora Tezi, 2005. 
7. Lok, A. Minatrea. The Effects of Intercessory Prayer on the Psychological Well-Being of College Students. Yayınlanmamış Doktora Tezi, Kansas University, 2001.

8. Meraviglia M.G. The Mediating Effects of Meaning in Life and Prayer on the Physical and Psychological Responces of People Experiencing Lung Cancer. Yayınlanmamış Doktora tezi, Tekxas University, 2001.

9. O'Laoire S. An Experimental Study of the Effects of Intercessory Prayer at-a Distance on Self Esteem, Anxiety and Depression. Yayınlanmamış Doktora Tezi, Institude of Transpersonal Psycholoy, California, 1993.

10. Rickerhauser D. R. Prayer as a Treatment Modality in Patient Healthcare: Physcians' Spiritual Beliefs and Religious Practices and their Relationship to Patient Health. Yayınlanmamış Yükses Lisans Tezi, Texas Pan American University, 2004.

11. Williams Russel H. An Emprical Investigation in to the Beneficial Effects Long Distance Intercessory Prayer on Student Retention and Grade Point Average. Yayınlanmamış Yüksek Lisans Tezi, Spalding University, 2001.

12. Wiegand C.E.K. The Effects of Prayer on Anxiety and Performance. Yayınlanmamış Doktora Tezi, Purdue University, 2004.

13. Woodmansee F.M. Mental Health and Prayer: an Investigation of Prayer, Temprament and the Effects of Prayer on Stress When Individuals Pray for Others. Yayınlanmamış Doktora Tezi, Spalding Üniversitesi, Kentucky, 2000.

14. M. Evren Hoşrik. Dua ve Plasebonun Siğiller Üzerindeki Etkisi. Yüksek Lisans Tezi, Ankara Üniversitesi, Ankara 2010.

\subsection{Makale Kataloğu}

1. Ai, A. L.- Peterson, C.- Bolling, S.F.-Koenig, H. "Private prayer and optimism in middle-aged and older patients awaiting cardiac surgery," The Gerontologist 42/1 (2002), 70-81.

2. Ai, Amy Lee- Bolling, F. Steven- Peterson, Christopher. "The use of prayer by coronary artery bypass patients," International Journal for the Psychology of Religion 10/4 (2000), 205-220.

3. Ai, A. L.- Peterson, C.-Tice, T.N.-Rodgers, W.- Bolling, S.F. "The influence of prayer coping onmental health among cardiac surgery patients: the role of optimism and acute distress," Journal of Health Psychology 12/4 (2007), 580-596.

4. Ai, A. L., at al., "The Role of Private Prayer in Psychosocial Recovery Among Midlife and Aged Patients Following Cardiac Surgery (CABG)" The Gerontologist 38/5 (1998), 591-601.

5. Ai, A. L., at al., "Types of Prayer, Optimism, and Well-Being of Middle- Aged and Older Patients Undergoing Open-Heart Surgery" Mental Health, Religion \& Culture 11/1(2008), 131-150.

6. Ai, A. L., at al., "Private Prayer and Quality of Life in Cardiac Patients: Pathways of Cognitive Coping and Social Support" Social Work in Health Care 48 /4 (2009), 471-494. 
7. Ambs, A. H.- Miller, M. F.- Smith, A. W.- Goldstein, M. S.- Hsiao, A.-F.- Barbash, R. B. "Religious and spiritual practices and identification among individuals living with cancer and other chronic disease" Journal of the Society for Integrative Oncology 5/2 (2007), 53-60.

8. Andersson, Gerhard. "Chronic pain and praying to a higher power: useful or useless?" Journal of Religion \& Health 47/2 (2008), 176-187.

9. Anderson, J., Nunnelley, P. A., "Private prayer associations with depression, anxiety and other health conditions: an analytical review of clinical studies" Postgraduate Medicine 128/7 (2016), 635-641.

10. Aviles, J. M., at al., "Intercessory Prayer and Cardiovascular Disease Progression in a Coronary Care Unit Population: A Randomized Controlled Trial", Mayo Clinic Proceedings 76 /12 (2001), 1192-1198.

11. Azhar, M. Z. \& Varma, S. L., "Religious Psychotherapy as Management of Bereavement" Acta Psychiatrica Scandinavica 91(1995), 233-235.

12. Azhar, M. Z.\& Varma, S. L., "Religious Psychotherapy in Depressive Patients" Psychotherapy and Psychosomatics 63 (1995), 165-168.

13. Azhar, M, Z., Varma, S.L. \& Dharap, A. S., "Religious Psychoterapy in Anxiety Disorder Patients" Acta Psychiatrica Scandinavica 90 (1994), 1-3.

14. Balboni, M. J.- Babar, A.- Dillinger, J. vd. "It depends: viewpoints of patients, physicians, and nurses on patientpractitioner prayer in the setting of advanced cancer," Journal of Pain and Symptom Management 41/5 (2011), 836-847.

15. Bearon, L. B., Koenig, H. G., "Religious Cognitions and Use of Prayer in Health and Illness" The Gerontologist 30/2 (1990), 249-253.

16. Benson, H., at al., "Study of the Therapeutic Effects of Intercessory Prayer (Step) in Cardiac Bypass Patients: A Multicenter Randomized Trial of Uncertainty and Certainty of Receiving İntercessory Prayer" American Hearth Journal 151/4 (2006), 935-942.

17. Boelens, P. T., at al., "The Effect of Prayer on Depression and Anxiety: Maintenance of Positive Influence One Year After Prayer Intervention", The International Journal of Psychiatry in Medicine 43/1(2012), 85-98.

18. Braam, A. W., at al., "Prayer and Depressive Symptoms in a Period of Secularization: Patterns Among Older Adults in The Netherlands" American Journal of Geriatric Psychiatry 15/4 (2007), 273 - 281.

19. Cotton, S.- Grossoehme, D.-McGrady, M.E. "Religious coping and the use of prayer in childrenwith sickle cell disease" Pediatric Blood \& Cancer 58/2 (2012), 244-249.

20. Crane, J. R.- Perlman, S. - Meredith, K. L. vd. "Women with HIV: conflicts and synergy of prayer within the realm of medical care," AIDS Education and Prevention 12/6 (2000), 532-543.

21. Dein, Simon- Pargament, Kenneth. "On not praying for the return of an amputated limb: conserving a relationship with God as the primary function of prayer," Bulletin of the Menninger Clinic 76/3 (2012), 235-259.

22. Duckro, Paul N., Magaletta, Philip R., "The effect of prayer on physical health: Experimental evidence", Journal of Religion and Health 33/3 (1994), 211219. 
23. Eisenberg, D. M., at. al., "Unconventional Medicine in the United States: Prevalence, Costs, and Patterns of Use" New England Journal of Medicine 328 (1993), 246-252.

24. Fehring, R. J.- Miller, J.F.- Shaw, C. "Spiritual Well-being, Religiosity, Hope, Depression, and Other Mood States in Elderly People Coping with Cancer", Oncology Nursing Forum, 4/24 (1997), 661-667.

25. Francis, L. J., at al., "Prayer and Psychological Health: A Study Among Sixthform Pupils Attending Catholic and Protestant Schools in Northern Ireland" Mental Health, Religion \& Culture 11/1 (2008), 85 - 92.

26. Halstead, M. T. \& Fernsler, J. I., "Coping Strategies of Long-Term Cancer Survivors" Cancer Nursing 17/2 (1994), 94 - 100.

27. Harris, W. S., at al., "A Randomized, Controlled Trial of the Effects of Remote, Intercessory Prayer on Outcomes in Patients Admitted to the Coronary Care Unit" Archives of Internal Medicine 159 (1999), 2273-2278.

28. Hekmati, N. P., Hojjati, H., "The relationship between praying and life expectancy in cancerous patients" Journal of Medicine and Life 8/4 (2015), 60-64.

29. Hollywell, Claire- Walker, Jan. "Private prayer as a suitable intervention for hospitalised patients: a critical review of the literature," Journal of Clinical Nursing 18/5 (2009), 637-651.

30. Ikedo, F., at al., "The Effects of Prayer, Relaxation Technique During General Anesthesia on Recovery Outcomes Following Cardiac Surgery" Complementary Therapies in Clinical Practice 13/2 (2007), 85-94.

31. Johnson, S.C. \& Spilka, B., "Coping with Breast Cancer: The Roles of Clergy and Faith" Journal of Religion and Health 30 (1991), 21-33.

32. Jors, K.- Büssing, A- Baumann, K.- Hvidt, N. "Personal Prayer in Patients Dealing With Chronic Illness: A Review of the Research Literature", Evidence-Based Complementary and Alternative Medicine, 5/1 (2015), 343355.

33. Kabat-Zinn, J., Massion, A. O., Kristeller, J., Peterson, L. G., at al., "Effectiveness of a meditation-based stress reduction program in the treatment of anxiety disorders." The American Journal of Psychiatry 149/7 (1992), 936-943.

34. Karati, K. T., at al., "The Interrelation of Prayer and Worship Service Attendance in Moderating the Negative Impact of Life Event Stressors on Mental Well-Being" Journal of Religion and Healt 57/6 (2018),2153-2166.

35. Kendler, K. S., at al., "Religion, Psychopathology and Substance Use and Abuse: A Multimeasure, Genetic-Epidemiologic Study" American Journal of Psychiatry 154 (1997), 322 - 329.

36. Keshavamurthy, B. R., "Prayers and healing an interdependent relation" Yoga Mimamsa 53 (2020), 64-68.

37. King, D. E. \& Bushwick, B., "Beliefs and Attitudes of Hospital İnpatients About Faith Healing and Prayer" Journal of Family Practice 39 (1994), 349352.

38. Koenig, H. G., Pargament, K.L, \& Nielsen, J., "Religious Coping and Health Status in Medically ill Hospitalized Older Adults" Journal of Nervous and Mental Helath Disease 186 (1998), 513 - 521. 
39. Ladd, K. L.- Spilka, Bernard. "Inward, outward, and upward: cognitive aspects of prayer," Journal for the Scientific Study of Religion 41/3 (2002), 475-484.

40. Laird, S. P., at al., "Measuring Private Prayer: Development, Validation, and Clinical Application of The Multidimensional Prayer Inventory" The International Journal for the Psychology of Religion 14/4 (2004), 251-272.

41. Leibovici, L., "Effects of Remote, Retroactive Intercessory Prayer on Outcomes in Patients with Bloodstream Infection: Randomized Controlled Trial" BMJ 323 (2001), 1450-1451.

42. Levine, E. G.- Aviv, C.-Yoo, G.- Ewing, C.- Au, A. "The benefits of prayer on mood and well-being of breast cancer survivors," Supportive Care in Cancer 17/3 (2009), 295-306.

43. Ly, Albert L., at al., "Perceptions of the Efficacy of Prayer and Conventional Medicine for Health Concerns" Journal of Religion and Health 59 (2020),118.

44. Maltby, John- Lewis, Christopher Alan-Day Liza. "Prayer and subjective wellbeing: the application of a cognitive-behavioural framework," Mental Health, Religion and Culture 11/ 1 (2008), 119-129.

45. Mao, J. J., at al., "Use of Complementary and Alternative Medicine and Prayer Among a National Sample of Cancer Survivors Compared to Other Populations without Cancer" Complementary Therapies in Medicine 15/1 (2007), 21-29.

46. Masters, K. S.- Spielmans, G. I. "Prayer and health: review, meta-analysis, and research agenda" Journal of Behavioral Medicine 30/4 (2007), 329-338.

47. Matthews, D. A., at al., "Effects of Intercessory Prayer on Patients with Rheumatoid Arthritis" Southern Medical Journal 93/12 (2000), 1177-1186.

48. McCaffrey, A. M.- Eisenberg, D. M.- Legedza, A. T. R.- Davis, R. B.- Phillips, R. S. "Prayer for health concerns: results of a national survey on prevalence and patterns of use," Archives of Internal Medicine 164/8 (2004), 858-862.

49. Meraviglia, Martha. "Effects of Spirituality in Breast Cancer Survivors," Oncology Nursing Form 33/1 (2006), 326-331.

50. Mickley, J. R., Soeken, K. \& Belcher, A., "Spiritual well-being Religiousness and Hope among Women with Breast Cancer" Journal of Nursing Scholarship 24/4 (1992), $267-272$.

51. Oyama, O. \& Koenig, H. G., "Religious Beliefs and Practices in Family Medicine" Archives of Family Medicine 7 (1998), 431-435.

52. O'laoire, S., "An Experimental Study of The Effects of Distant, Intercessory Prayer on Self-Esteem, Anxiety, and Depression" Alternative Therapies in Health and Medicine 3/6 (1997), 38-53.

53. Palmer, R. F., at al., "A Randomized Trial of the Effects of Remote Intercessory Prayer: Interactions with Personal Beliefs on Problem-Specific Outcomes and Functional Status" The Journal of Alternative and Complementary Medicine 10/3 (2004), 434-448.

54. Poloma, M. M. \& Pendleton, B. F., "Religious Domains and General WellBeing" Social Indicators Research 22 (1990), 255 - 276. 
55. Paloma, M. P.- Pendleton, B. F. "The effects of prayer and prayer experiences on measures of general well-being," Journal of Psychology andTheology 19/1 (1991), 71-83.

56. Poloma, M. M.- Lee, M. T. "From prayer activities to receptive prayer: godly love and the knowledge that surpasses understanding," Journal of Psychology and Theology 39/2 (2011), 143-154.

57. Rainville, G., "The Interrelation of Prayer and Worship Service Attendance in Moderating the Negative Impact of Life Event Stressors on Mental WellBeing" Journal of Religion and Healt 57/6 (2018), 2153-2166.

58. Raleigh, E. D., "Sources of Hope in Chronic İllness" Onchology Nursing Forum 19 (1992), 443-448.

59. Rezaei, M.-Hajbaghery, M.- Seyedfatemi, N.- Hoseini, F. "Prayer in Iranian cancer patients undergoing chemotherapy," ComplementaryTherapies in Clinical Practice 14/2 (2008), 90-97.

60. Rhee, S. M., at al., "Use of Complementary and Alternative Medicines by Ambulatory Patients" Archives of Internal Medicine 164/9 (2004), 10041009.

61. Richmond, J. A.- Bailey, D. E.- McHutchison, J. G.- Muir, A. J. "The use of mindbodymedicine and prayer among adult patients with chronic hepatitisC," Gastroenterology Nursing 33/3 (2010), 210-216.

62. Ridge, D., at al., "Like a Prayer: The Role of Spirituality and Religion for People Living with HIV in the UK" Sociology of Health\&Illness 30/3 (2008), 413- 428.

63. Rippentrop, A.E.-Altmaier, E.M.- Chen, J.J.- Found, E.M.-Keffala, V.J. "The relationship between religion/spirituality and physical health, mental health, and pain in a chronic pain population," Pain 116/3 (2005), 311-321.

64. Roberts, J. A., Brown, D., Elkins, T. \& Larson D. B., "Factors Influencing Views of Patients with Gynecologic Cancer about end-of-life Decision" American Journal of Obstetrics and Gynecology 176 (1997), 166-172.

65. Sahebnasagh, Adeleh, at al., "The Influence of Prayer on Critical Patients Admitted to the Intensive Care Unit" Critical Comments In Biomedicine $1 / 1(2020)$.

66. Smith, A. R.- De Santo S.- Madeya, J. E.- Tracey E.F.- De Cristofaro, S.Mukkamala, L. "How women with advanced cancer pray: a report from two focus groups," Oncology Nursing Forum 39/3 (2012), 310-316.

67. Taylor, E. J.- Outlaw, F.H. "Use of prayer among persons with cancer," Holistic Nursing Practice 16/3 (2002), 46-60.

68. Taylor, E. J.- Outlaw, F. H.- Bernardo, T. R.- Roy, A. "Spiritual conflicts associated with praying about cancer," Psycho- Oncology 8/5 (1999), 386394.

69. Turton, D. W. \& Francis, L. J., "The Relationship Between Attitude Toward Prayer and Professional Burnout Among Anglican Parochial Clergy in England: Are Praying Clergy Healthier Clergy?" Mental Health, Religion \& Culture 10/1 (2007), 61 - 74.

70. Vannemreddy, P., at al., "Influence of Prayer and Prayer Habits on Outcome in Patients With Severe Head Injury" American Journal of Hospice and Palliative Medicine 26/4 (2009), 264-269. 
71. Walton, Joni.-Sullivan, Nancy. "Men of prayer: spirituality of men with prostate cancer: a grounded theory study," Journal of Holistic Nursing 22/2 (2004), 133-151.

72. Whittington, B. L.- Scher, S. J. "Prayer and subjective well-being: an examination of six different types of prayer," International Journal for the Psychology of Religion 20/1 (2010), 59-68.

73. Yates, J. S.- Mustian, K. M.- Morrow, G. R. vd. "Prevalence of complementary and alternativemedicine use in cancer patients during treatment" Supportive Care in Cancer 13/10 (2005), 806-811.

\section{Sonuç}

Çalışma kapsamında 1990- 2020 yılları arasında yapılmış olan toplam 87 tez incelenmiş ve yüksek yayınlanmış makalelerin $(n=73)$ lisansüstü tezlerden $(n=14)$ fazla olduğu saptanmıştır.

Yapılan çalışmada yayımlanan çalışmaların yıllara göre dağılımı dikkate alındığında en çok 2007 (n=8) yılında, en az ise $2006(n=1), 2014$ (n=1), 2015 $(n=1), 2016(n=1)$ ve 2018 (n=1) yıllarında yayımlandığı görülmüştür.

Hastalık ve dua ilişkisi konusunda 1990- 2020 yılları arasında yayımlanan lisansüstü tez çalıșmaları yapıldığı üniversite ve yıllara göre analiz edildiğinde en fazla Spalding Üniversitesi $(n=4)$, en az ise Marmara Üniversitesi $(n=1)$, Ankara Üniversitesi $(n=1)$, Palo Alto Üniversitesi $(n=1)$, Kansas Üniversitesi $(n=1)$, Purdue Üniversitesi $(n=1)$, Texas Üniversitesi $(n=1)$, Texas Pan Üniversitesi $(n=1)$ ve Walden Üniversitesi $(n=1)$ 'nda olduğu görülmüştür.

Lisansüstü tezlerin ve makalelerin incelenmesi sonucunda anket, deney, görüşme/mülakat, belge tarama/dökümantasyon ve gözlem şeklinde 5 başlık belirlenmiş ve çalıșmalar buna göre sınıflandırılmıștır. İncelenen araștırmalar arasında en fazla anket tekniğinin $(n=41)$ kullanıldığı saptanmıştır. Nitel araştırma yöntemlerinden belge tarama/dokümantasyon (n=9) ve görüşme/mülakat $(n=19)$ ile veri toplandığı tespit edilmiştir. Anket tekniği, kısa zamanda çok sayıda kişiye az maliyetle ulaşabilme imkânı tanımaktadır. Bu durumun hastalık ve dua araştırmalarında veri toplama araçları içerisinde anket tekniğinin tercih edilebilirliğini arttırdığı söylenebilir.

İncelenen 87 lisansüstü tez ve makale çalıșmasında örneklem olarak toplam 7 çalışma grubu tespit edilmiştir. Veriler incelendiğinde en fazla çalışılan örneklem gruplarının hasta bireyler $(\mathrm{n}=48)$ en az çalıșllan gruplar ise yerel halk $(n=7)$, doktorlar $(n=1)$, din görevlileri $(n=1)$ lise öğrencileri $(n=1)$, sporcular $(n=1)$ ve esnaflar $(n=1)$ olduğu görülmektedir. Yapılan araștırmalar doğrultusunda örneklem olarak en fazla hasta bireylerin tercih edilmesinin çalışılan konudan kaynaklandığı söylenebilir.

Yapılan çalışma çerçevesinde elde edilen veriler doğrultusunda konu ile ilgili önerilerimiz:

Hastalık ve dua ilişkisini konu edinen çalımalar incelendiğinde ülkemizde yapılmış olan çalışmaların yurtdışında yapılan çalışmalara oranla belirgin derece az olduğu tespit edilmiştir. Bu bağlamda ülkemizde hastalık ve dua ilişkisine yönelik yapılacak daha çok çalışmaya ihtiyaç vardır. İlgili çalışmaların 
gerçekleștirilebilmesi için hastalık ve dua ilişkisini konu edinen lisansüstü tezler nicel olarak arttırılabilir, ilgili konu sempozyum ve çalıştay gibi akademik toplantılarda ana tema olarak işlenebilir.

Hastalık ve dua ilișkisi konusunda yapılmıș olan mevcut araștırmaların veri toplama teknikleri incelendiğinde anket, deney, mülakat/görüşme ve belge tarama/dökümantasyon yöntemlerinin çoğunlukla ayrı ayrı kullanıldığı bu anlamda karma yöntemle yapılacak olan çalışmalara ihtiyaç olduğu görülmektedir. Karma yöntem yapılan çalışmalarda konunun farklı perspektifle daha derin araştırılması imkânı sağlamaktadır. Örneğin, anket tekniğinin kullanıldığı araştırmalar nicelik olarak daha fazla veri sunarken mülâkat tekniği ile gerçekleştirilen araştırmalar ise nitelik olarak daha fazla veri sağlamaktadır. Diğer taraftan belge tarama yöntemi kullanılan araștırmalar ise saha çalıșmaları olmaksızın konuyla ilgili literatüre daha fazla hâkim olma ve tüm çalışmaları görebilme imkânı vermektedir.

Yapılan çalışmalarda kanser hastalığına yönelik araştırmaların sayısal çoğunlukta olduğu görülmüştür. Çeşitli hastalıkların da göz önünde bulundurularak araştırma yöntemleri ve örneklemi çeşitlendirilerek karşılaştırmalı şekilde araştırılması bu alandaki literatüre katkı sağlayacaktır.

\section{Finansman / Funding:}

This research received no external funding. / Bu araştırma herhangi bir dış fon almamiștır.

Çıkar Çatışması / Conflicts of Interest:

The author declare no conflict of interest. / Yazar, herhangi bir çıkar çatışması olmadığını beyan eder. 


\section{Kaynakça}

Ai, A. L., at al. "The Role of Private Prayer in Psychosocial Recovery Among Midlife and Aged Patients Following Cardiac Surgery (CABG)”. The Gerontologist 38/5 (1998), 591-601.

Ambs, A. H.- Miller, M. F.- Smith, A. W.- Goldstein, M. S.- Hsiao, A.-F.- Barbash, R. B. "Religious and Spiritual Practices and Identification Among Individuals Living With Cancer and Other Chronic Disease". Journal of the Society for Integrative Oncology 5/2 (2007), 53-60.

Apaydın, Halil. Din Psikolojisi Terimler Sözlüğü. İstanbul: Ayıșığı Kitapları, 2001.

Aviles, J. M., at al. "Intercessory Prayer and Cardiovascular Disease Progression in a Coronary Care Unit Population: A Randomized Controlled Trial”. Mayo Clinic Proceedings 76 /12 (2001), 1192-1198.

Aytaçlı, Berrak. "Durum Çalışmasına Ayrıntılı Bir Bakış”, Adnan Menderes Üniversitesi Eğitim Fakültesi Eğitim Bilimleri Dergisi 3/1 (2012), 1-9.

Azhar, M, Z., Varma, S.L. \& Dharap, A. S. "Religious Psychoterapy in Anxiety Disorder Patients”. Acta Psychiatrica Scandinavica 90 (1994), 1-3.

Azhar, M. Z. \& Varma, S. L. "Religious Psychotherapy as Management of Bereavement". Acta Psychiatrica Scandinavica 91(1995), 233-235.

Benson, H., at al. "Study of the Therapeutic Effects of Intercessory Prayer (Step) in Cardiac Bypass Patients: A Multicenter Randomized Trial of Uncertainty and Certainty of Receiving İntercessory Prayer". American Hearth Journal 151/4 (2006), 9 935-942.

Braam, A. W., at al. "Prayer and Depressive Symptoms in a Period of Secularization: Patterns Among Older Adults in The Netherlands". American Journal of Geriatric Psychiatry 15/4 (2007), $273-281$.

Carlson, C. R., Bacaseta, P. E. \& Simanton, D. A. “A Conrtolled Evaluation of Deveational Meditation and Progressive Relaxation". Journal of Psychology and Theology 16 (1988), 362-368.

Cobuild, Collins. Advanced Leraner's English Dictionary. London: Harper Collins Publisher, 1998.

Dein, Simon- Pargament, Kenneth. "On Not Praying for The Return of An Amputated Limb: Conserving A Relationship With God as The Primary Function of Prayer". Bulletin of the Menninger Clinic 76/3 (2012), 235-259.

Faris, İ. Ebu'l-Huseyn Ahmed Bin Zekeriya Mekayisu'l Lügah. Thk. Muhammed Avz Murib. Beyrut: Daru İhyai't Türasi'l Arabi, 1422/2001.

Felsefe Terimleri Sözlüğü (TDK). Erișim 2 Nisan 2019. https://sozluk.gov.tr/

Halstead, M. T. \& Fernsler, J. I. “Coping Strategies of Long-Term Cancer Survivors”. Cancer Nursing 17/2 (1994), $94-100$.

Harris, W. S., at al. "A Randomized, Controlled Trial of the Effects of Remote, Intercessory Prayer on Outcomes in Patients Admitted to the Coronary Care Unit". Archives of Internal Medicine 159 (1999), 2273-2278.

Johnson, S.C. \& Spilka, B. "Coping with Breast Cancer: The Roles of Clergy and Faith". Journal of Religion and Health 30 (1991), 21-33.

Jors, K.- Büssing, A- Baumann, K.- Hvidt, N. “Personal Prayer in Patients Dealing With Chronic Illness: A Review of the Research Literature". Evidence-Based Complementary and Alternative Medicine 5/1 (2015), 343-355.

Kabat-Zinn, J., Massion, A. O., Kristeller, J., Peterson, L. G., at al., “Effectiveness of A Meditation-Based Stress Reduction Program in The Treatment of Anxiety Disorders". The American Journal of Psychiatry 149/7 (1992), 936-943.

Kaleli Yılmaz, Gül. “Durum Çalışması”, Kuramdan Uygulamaya Eğitimde Bilimsel Araştırma Yöntemleri, ed. Mustafa Metin. 261-285. Ankara: Pegem Akademi, 2014.

Kendler, K. S., at al. "Religion, Psychopathology and Substance Use and Abuse: A Multimeasure, Genetic-Epidemiologic Study". American Journal of Psychiatry 154 (1997), 322 - 329.

Koenig, H. G., Pargament, K.L, \& Nielsen, J. "Religious Coping and Health Status in Medically Ill Hospitalized Older Adults". Journal of Nervous and Mental Helath Disease 186 (1998), 513 - 521.

Leibovici, L. "Effects of Remote, Retroactive Intercessory Prayer on Outcomes in Patients with Bloodstream Infection: Randomized Controlled Trial”. BMJ 323 (2001), 1450-1451.

Lesermen, J. Et al. "The Efficacy of the Relaxation Response in Preparing for Cardiac Surgery". Behavioral Medicine 15/3 (1989).111-117.

Levine, E. G.- Aviv, C.-Yoo, G.- Ewing, C.- Au, A. "The Benefits of Prayer on Mood and Well-Being of Breast Cancer Survivors". Supportive Care in Cancer 17/3 (2009), 295-306. 
Maltby, John- Lewis, Christopher Alan-Day Liza. "Prayer and Subjective Wellbeing: The Application of A CognitiveBehavioural Framework”. Mental Health, Religion and Culture 11/ 1 (2008), 119-129.

Mao, J. J., at al. "Use of Complementary and Alternative Medicine and Prayer Among a National Sample of Cancer Survivors Compared to Other Populations without Cancer". Complementary Therapies in Medicine 15/1 (2007), 21-29.

McCaffrey, A. M.- Eisenberg, D. M.- Legedza, A. T. R.- Davis, R. B.- Phillips, R. S. "Prayer for Health Concerns: Results of A National Survey on Prevalence and Patterns of Use". Archives of Internal Medicine 164/8 (2004), 858-862.

Mickley, J. R., Soeken, K. \& Belcher, A. "Spiritual well-being Religiousness and Hope among Women with Breast Cancer". Journal of Nursing Scholarship 24/4 (1992), 267 - 272.

Miller, R. N. "Study on The Efectiveness of Remote Mental Healing". Medical Hypotheses 8/5 (1982), 481- 490.

Morris, P.A. "The Effect of Pilgrimage on Anxiety, Depression and Religious Attitude”. Psychological Medicine 12 (1982), $291-294$.

O'laoire, S. “An Experimental Study of The Effects of Distant, Intercessory Prayer on Self-Esteem, Anxiety, and Depression". $\quad$ Alternative Therapies in Health and Medicine 3/6 (1997), 38-53.

Özen, Âdem. Yahudilikte İbadet. İstanbul: Ayıșığı Kitapları, 2003.

Palmer, R. F., at al. "A Randomized Trial of the Effects of Remote Intercessory Prayer: Interactions with Personal Beliefs on Problem-Specific Outcomes and Functional Status". The Journal of Alternative and Complementary Medicine 10/3 (2004), 434-448.

Raleigh, E. D. "Sources of Hope in Chronic Illness". Oncology Nursing Forum 19 (1992), 443-448.

Rezaei, M.-Hajbaghery, M.- Seyedfatemi, N.- Hoseini, F. "Prayer in Iranian Cancer Patients Undergoing Chemotherapy". Complementary Therapies in Clinical Practice 14/2 (2008), 90-97.

Roberts, J. A., Brown, D., Elkins, T. \& Larson D. B. "Factors Influencing Views of Patients with Gynecologic Cancer about end- of-life Decision". American Journal of Obstetrics and Gynecology 176 (1997), 166-172.

Smith, A. R.- De Santo S.- Madeya, J. E.- Tracey E.F.- De Cristofaro, S.- Mukkamala, L. "How Women With Advanced Cancer Pray: A Report from Two Focus Groups". Oncology Nursing Forum 39/3 (2012), 310-316.

Sodestrom, K. E., Martinson, M. “Patients Spiritual Coping Strategies: A Study of Nurse and Patient Perspectives". Oncol Nurs Forum 14/2 (1987).

Subaşı, Münevver- Okumuş, Kübra. "Bir Araştırma Yöntemi Olarak Durum Çalışması”. Atatürk Üniversitesi Sosyal Bilimler Enstitüsü Dergisi 21/2 (2012), 419-426.

World Healt Organization, Healt Promotion Glossary. Geneva: World Healt Organization,1998.

Yates, J. S.- Mustian, K. M.- Morrow, G. R. vd. "Prevalence of complementary and alternativemedicine use in cancer patients during treatment". Supportive Care in Cancer 13/10 (2005), 806-811. https://islamansiklopedisi.org.tr/dua (TDV, 7 Eylül 2021).

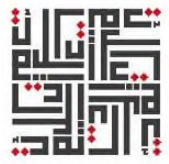

